At-Turats

Jurnal Pemikiran Pendidikan Islam

journal homepage: http://jurnaliainpontianak.or.id/index.php/atturats

\title{
PARADIGM SHIFT ON ISLAMIC HIGHER EDUCATION IN INDONESIA: LEARNING FROM UIN MALIKI MALANG EXPERIENCE
}

\author{
Aries Musnandar \\ Postgraduate \\ Universitas Islam Raden Rahmat (UNIRA) Malang \\ East Java Indonesia
}

\begin{abstract}
A B S T R A K
Artikel ini terbatas pada perubahan institusi pendidikan tinggi islam (universitas) di Indonesia yang meneliti penggunaan beberapa istilah yang menandakan islam dan pendidikan, dan menyediakan pedoman untuk menjelaskan kegunaannya dalam wacana konsep pendidikan. Dengan ini, artikel menggambarkan klasifikasi pendidikan islam dan institusi yang berkaitan. Dipengaruhi oleh perkembangan globalisasi dalam hal kemajuan di masyarakat dan seiring perubahan ilmu pengetahuan dan teknologi juga dibahas pada tulisan ini. Artikel ini membahas dikotomi antara ilmu pengetahuan dan subjek islam yang harus disampaikan pada universitas umum dan institusi pendidikan berbasis islam. Wacana ini menjadi pembahasan yang panjang di Indonesia sampai saat ini, tulisan ini menggunakan pendekatan kualitatif dan sebagai metode penelitian. Diikuti dengan hasil wawancara kepada informan dan pembelajaran literasi sebagai teknik utama untuk mendukung pergeseran paradigma pada pendidikan islam di Indonesia khususnya di UIN Maliki Malang. Maka, sumber pertama dan kedua digunakan pada metode kualitatif. Artikel ini menyimpulkan bahwa kunci motivasi dan karakteristik dari keseluruhan bagian dan tujuan program pendidikan dibagi antara pendidikan tradisional islam (dipesantren) dan tradisi barat atau pendidikan modern sampai saat ini. Pengalaman Universitas Islam (UIN Maliki Malang) untuk melaksanakan konsep baru pada manajemen pendidikan yang berkombinasi antara tradisi pesantren dan universitas (tradisi barat) akan dipaparkan dalam tulisan ini.
\end{abstract}

Kata kunci: konsep pendidikan islam, perubahan pendidikan tinggi islam (universitas), UIN Maliki Malang

\section{INTRODUCTION}

The world today is experiencing dynamic change. The change is not only on the physical aspect of environment, such as new building, new road, and infrastructure and so on, but changes also shaped nonphysical as value, tradition and social ideas. Changes in the non-physical aspects of an ongoing culture change is not as fast as the physical aspect, and occurs in an effort to accommodate the physical changes that are material aspects. Bennis and Suojanen

${ }^{1}$ Rice \&Bishoprick 1971.Conceptual Models of Organization. Merdith Corporation. NY. USA,
(Rice \&Bishoprick in 1971) said that the new values that thrive in the modern world will be followed by the formation of a pattern of behavior that is tailored to community values. In principle, modern society can not be separated from the two twin influences that could determine the direction of change and concepts, values, ideas, theories and paradigms that influence society namely democracy and science. ${ }^{1} \mathrm{I} n$ science and technology, actually the West's advances just lasted several centuries ago. 
The history of advances Western science began after obtaining repertoire of general knowledge from Muslim scholars when they colonized the Muslim world around the 16th-19th century AD. A number of works of science from Muslim scholars were taken and translated into their language to be learned. Since that the West science and technology developed rapidly, but they did not believe in religion as a worldview that can shape human civilization, filtering inappropriate science. Therefore, they separate religion froms cience and technology progress in the community. The process of separation phenomenon is known as secularization.

Long before that, Muslims attention to science and technology were very high, as revealed in the Qur'an, which means "It was We who taught him the making of coats of mail for your benefit, to guard you from each other's violence..."..(QS 17: 80).It is clear that people are required to do something by means of technology. So it is not surprising that in the 7 th century AD many Islamic thinkers that formidable productive and innovative in the development of science and technology. Muslims pioneering and excellence in the science is proven. But, unfortunately the progress is not followed up continuously. Then, the West has led and taken over science up to date.

Western character always wanted to rule the world even though the colonialism was over. The term globalization often used by the West to influence developing countries which is actually a form of coercion or called neo colonialism. Globalization is not only in economics, and technology, but almost in all aspects of human life including education. The nature of globalization in education has started since the West invaded the Islamic world. From here emerged the term dichotomous education that separates religion with Western education as known as secular education. It was in the colonial era Indonesia had quite a lot traditional institutions on Islamic religious education, but apart from modern Western education. Dichotomous view which grow-develop in the colonial period possessed also some traditional Muslims who regarded a modern Western education belong to infidels so that must be separated from the Islamic education. This paradigm made Islamic education having limited sense that only related to Islamic law, fiqh, aqeedah, tawheed, read or recites the Quran, Hadith and other mahdhoh worships. While the signs of Allah Almighty on the development of science, technology and human civilization did not become a concern to Islamic educational institution to be included in its curriculum. In contrast, the West through its education has become super power in the field of science and technology.

\section{ISLAMIC EDUCATION CONCEPT}

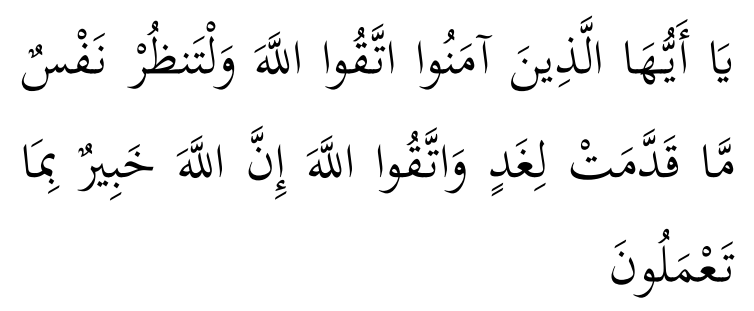

"O ye who believe! Fear Allah, andlet every soul look to what (provision) he has sent forth for the morrow. Yea, feer Allah: for Allah is well acquainted with (all) that ye do". (QS: Al Hasyr; 59: 18).

".........Allah will rise up, to (suitable) ranks (and degrees), those who believe and who have been granted Knowledge..." (QS: Al Mujadallah; 58: 11).

Education has an important meaning in human life. Through education, quality of human resources can be optimally improved which will form an advanced civilization up to the welfare of mankind. Countries concerned with the quality of education will prosper the people. The increasing prosperity allows people to have access for good education. As a result, 
prosperous society can be achieved through education. Connectedness between education and people welfare depicted in the cycle below:

The Cycle of Education Role for People Welfare

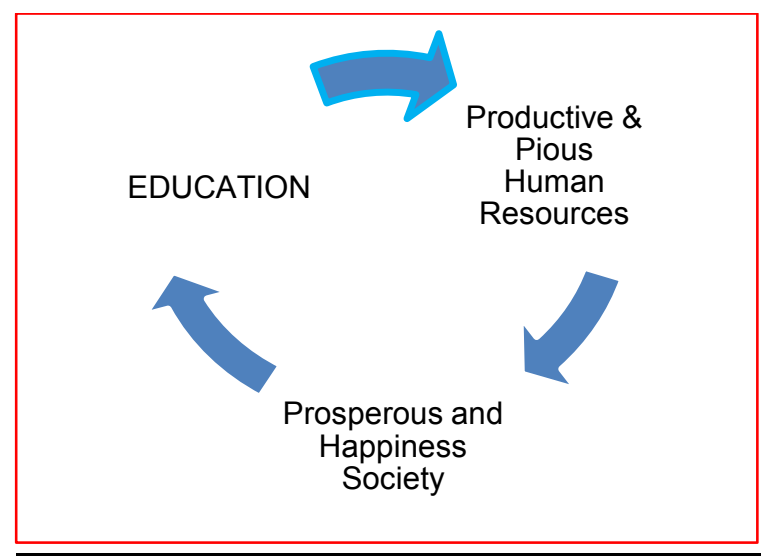

(Picture 1)

Cycle shows how important education system in a country. From the Islamic perspective, education that is built on the basis of pious (taqwa) will create prosperous and happiness society as coveted by Muslims. However, one of some important issues in Islamic education today is how does the Islamic education system read the dynamics of change in society. Is the Islamic educational system still on the right path?

The Islamic Education term often interchangeably with the term Islamic Religious Education (IRE). It seems the same but difference. Often found people mistakenly revealed on Islamic education but actually they want to explain IRE which is defined as the lesson, this is similar with Mathematics Education (the name of subject is Mathematics). Therefore, IRE in this context can be understood as an activity or attempts to teach the religion (Islam). While Islamic education is a system of Islamic education. This is the same for instance with military education system. If Islam is a system of education, then it means that there are a number of elements to educate Muslims based on the Qur'an and Hadith. Furthermore, according to Muhaimin, IRE is an integral part of Islamic education in the perspective to instill its values in order to be a way of life a Muslim. Thus, IRE is part of the Islamic education system. $^{2}$

\section{STATUS CHANGE OF ISLAMIC EDUCATION INSTITUTION: STAIN-IAIN-UIN}

One by one Islamic Higher education institutions such as the College of Islamic Studies (STAIN) and the State Islamic Institute (IAIN) have changed their institutions status. STAIN changed to IAIN and from IAIN turned into the State Islamic University (UIN). However, there are actually two models which still becoming discourses. First, STAIN and IAIN are considered to develop knowledge of Islamic subjects only for instance, Ushuluddin, Shariah, adab, tarbiyah and dakwah. Second, the university institution in which its curriculum consists of general knowledge and knowledge-based religions. However, the last model has not yet succeeded to have graduates who master on sciences as well as the Islamic subject at once.Therefore, the change of IAIN and STAIN to become Islamic University is to give greater mandate andintended to create scientists' ulema and or ulema's scientist.

Islamic universities are generally plagued by weaknesses in its various aspects, namely, planning, workforce, funding, facilities and infrastructure and even the low public trust. Moreover, in many cases, not least among higher education institutions Islam failed to formulate a vision and mission so that failed to establish the maximum power to move 
on. Various issues like autonomy, democracy, entrepreneurship and so on, have influenced organizational change.

\section{THE INSTITUTIONAL CHANGE FROM STAIN MALANG TO UIN MALANG}

Observing the policy process experienced by UIN Malang from a College to a university can be described as something "special". As Arsyad Azhar said, former Rector of UIN Alauddin Makassar, that what is experienced by UIN Malang is a quantum leap. In fact, the commentary said that what was done by Prof. Imam Suprayogo as "madness". Generally, the proposed changes should be from STAIN to IAIN then into UIN: ${ }^{3}$

In'am (2012) delineated the stages of institutional change of STAIN Malang became UIN Maliki Malang from the picture below: ${ }^{4}$

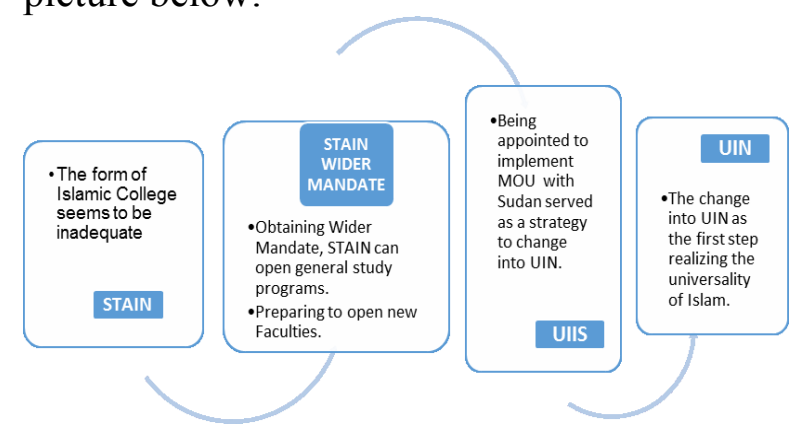

Picture 2 Stages of Institutional Change

The institutional changes from STAIN to UIN take the following stages:

a. Stage of Building Awareness

This stage was conducted for example by arranging study visits to Christian universities to provide empirical facts on advancement of the private Christian higher educational institution. By these visits, it is

\footnotetext{
${ }^{3}$ Arsyad, Azhar (2011). "the Real Khalifah" dalam Barizi dan Mujtahid (ed.), Membangun Pendidikan Islam dalam Bingkai Islam Lintas Batas. Malang: UIN-Maliki Press.
}

expected to call the awareness of STAINMalang is left behind other private educational institutions.

In addition, building awareness is also through non-formal dialogues on the campus development after being STAIN Malang which originally was Faculty of Tarbiyah, the IAIN Surabaya's branch. As an autonomous STAIN that is no longer dependent on the chief institution, IAIN has, therefore, to think about future development.

b. Stage of Conception and Planning Stage of Conception and Planning was conducted through the creation of the STAIN's Strategic Development Plan for 10 Years ahead. In this Strategic Plan declared hat, in addition to the development of strategic programs in academic, institutional, and staff business, STAIN should have changed its status into university in the next ten years.

c. Stage of Actualization/implementation Stage of implementation is based on the drafted strategic plan. In the early phases, the development including strategic programs such as the Special Programme for Arabic Language Development(PKPBA), improvement of infrastructure, establishment of ma'had aly, and the development of cooperation networks.

Changes in the status of STAIN to UIN through some efforts as below:

1) Submission proposals, Strategic Program Development, the Expansion Mandate

Rector and staff created a number of proposals related to the institutional

4 Muhammad, In'am Esha (2012). Universitation of Stain Malang: Policy Analysis on Institutional Change in the Perspective of Philosophy of Value. Makalah, Seminar International 1-2 Desember 2012 di SekolahPascasarjana UIN Maliki Malang 
changes submitted to the higher authorities. At this stage a high level of communication and negotiation conducted by the Rector, Prof. Imam Suprayogo to convince officials that have authority for organizational change. Many people even internally who consider the Rector's step as mission impossible,'crazy' and dreamer and there are advised not to impose his ideas because it will be laughed at others.

Unfavorable environment among the internal has been ignored by Prof. Imam Suprayogo, but the intensity of communication and personalized approach are continued. He made a personal approach to President Abdurrahman Wahid for inviting him to visit his campus in order to learn more about developments of STAIN Malang and some strategic preparations that have been made if it will turn into a university. Imam Suprayogo's communication to external parties could be considered as "good public relations" and useful to improve the image of STAIN. On the other hand, Imam Suprayogo keeps on communication to the internal academic community in order to share the "dream" to change STAIN into UIN Malang. "I am the dreamer and in order to make the dream comes true then I motivate everyone to dream", he said. Communication is not only conducted orally but, also written through the publication of books which contain the vision \& mission, tradition, the meaning of Ulul Albab, dreams of STAIN Malang and Science Development Paradigm. At the time, the expansion of the mandate (STAIN Wider Mandate), to be utilized to establish Ma'had Aly and prepare graduate programs as well as open general programs such as English language education and so on. This mandate is a strategic stuff, thus to obtain university status is a matter of time only.

2). Institutional Change of STAIN intoUIIS Changes to UIIS STAIN Malang (Universitas Islam Indonesia - Sudan) showed an advantage for institutions that will transform itself into a university. Change to become UIIS is very strategic and a "blessing in disguise" approaching the expected realization of a university. UIIS inauguration held on Sunday, July 21, 2002 by the Vice President of Indonesia, Dr. Hamzah Haz, witnessed by the Vice President I of Sudan, Ali Osman Mohamed Taha, along with a number of ministers of the two countries, Indonesia and Sudan. STAIN Malang was appointed by the Minister of Religious Affairs to implement the MoU based on the evaluation of both the Ministry of Religious Affairs of Indonesia and Sudan. A number of IAIN and STAIN nominated to run this MoU but ultimately the team decided that the most appropriate one is STAIN Malang with the following reasons: (1) it has a variety of general courses not only religion study program, (2) it has an intensive program of foreign languages (Arabic and English), (3) its has ma'had aly (dormitory) which can accommodate students in huge quantity, (4) strategic campus location for development of higher education especially Malang is also known as the city of education, (5) STAIN Malang has planning clearly related to the physical development and academic development in the future.

\section{3). Change from UIIS to UIN}

The change STAIN Malang to UIIS in fact raises the issue that the education system in Indonesia does not allow educational institutions using the name of the foreign country. Finally, the name UIIS must be replaced and change it into UIN through Presidential Decree no. 50 of 2004 which preceded joint decision by the Ministry of Religious Affairs and Ministry of National Education of Indonesia. The change process 
of UIN Malang was quite interesting because it came from bottom up approach and different from with IAIN Jakarta and IAIN Yogyakarta which initiated from the top that was the Minister of Religious Tarmizi Taher who applied government policy to change status of such IAINs above into university ${ }^{5}$.

\section{EDUCATION AT UIN MALIKI MALANG}

The Educational program activity in UIN Maliki is derived from the ideas of Prof. Imam Suprayogo in integrating the pesantren traditions and university's traditions (modern education). According to Imam Suprayogo Islamic studies is an integral part, related, universal and indivisible unity in understanding Islam as rahmatan lilalamin. Then, a new pattern of Islamic studies should be placed on the power of the verses qawliyyah and kauniyah. Islamic studies should be translated in the context of integrative and universal life that brings happiness and safety in this world and the hereafter, as spoken in prayer every Muslim: "Robbanaatina fiddunya hasanah wafil akhiroti hasanah waqina adzabannar".

\section{INTEGRATION BETWEEN SCIENCE AND ISLAM}

Imam Suprayogo realizes that setbacks Islamic educational institutions due to the strength of the dichotomous view that separates between science and religion (Islam). Islamic society begin to realize that ignoring one or both of the qawliyyah and kauniyah verses would cause great harm to the people. Muslims are expected will not go to the wrong path and losing. In this context Imam Suprayogo thought to combine the values obtained from the two categories of verses above into a single unit, and then became the foundation of

${ }^{5}$ Hadyand Rasmianto, 2004:36; Rasmianto, et al., 2004: 234; Suprayogo and Rasmianto, 2008:108 education for students at UIN Maliki Malang. Synergy of the two led to four power expected of each student UIN Malang, namely: (1) the breadth of knowledge, (2) professional maturity, (3) Islamic morality, and (4) spiritual depth.

New students at UIN Maliki Malang must live for a year in the dorms (Ma'had). The students are to follow Islamic education while improving language skills required in understanding the verses qawliyyah and kauniyyah through the ability to comprehend Arabic and English. The main objective of this course is to bring students into the real academician who has a breadth of knowledge and professional in their field with strength of Islamic moral character and spiritual depth.

According to Imam Suprayogo integration of science and religion (Islam) in fact can be understood from the divine revelation that some of them have been quoted on the beginning of this paper. The God's revelation is not apparent dichotomy between science and Islam because Islam is a religion as well as source for developing sciences. Implementation of Islamic teachings in daily life must be based on the verses qawliyyah and kauniyyah and the Prophet Muhammad is a role model in all aspects of life that we can learn from Hadith and his sirah Nabawiyyah.

The integration of pesantren's traditions and universitiy's traditions could become ideal educational goals for graduates of UIN Maliki Malang in order to prepare scientists' ulema and or ulema's scientist. Hopefully, the shortage of qualified ulemas who understand the science, as well as the less qualified scientists who comprehend the values of religion (Islamic teachings), can be solved out significantly. Finally, we can achieve the mission to create productive and pious human resources. Being a good man in term 
of al insan al kamil is expected in order to present himself as Khalifatul fil ard.

Finally, UIN Maliki Malang through his education program can contribute for improving Muslim quality in Indonesia. Therefore, UIN Maliki Malang has been developing concepts on the integration of science and Islam, through Pohon Ilmu or scientific tree and the integration of qawliyyah and kauniyyah verses or the integration between religious and general sciences (see picture 3 and 4 below).

Picture 3

The Scientific Tree of UIN Maulana Malik Ibrahim (UIN MALIKI) Malang

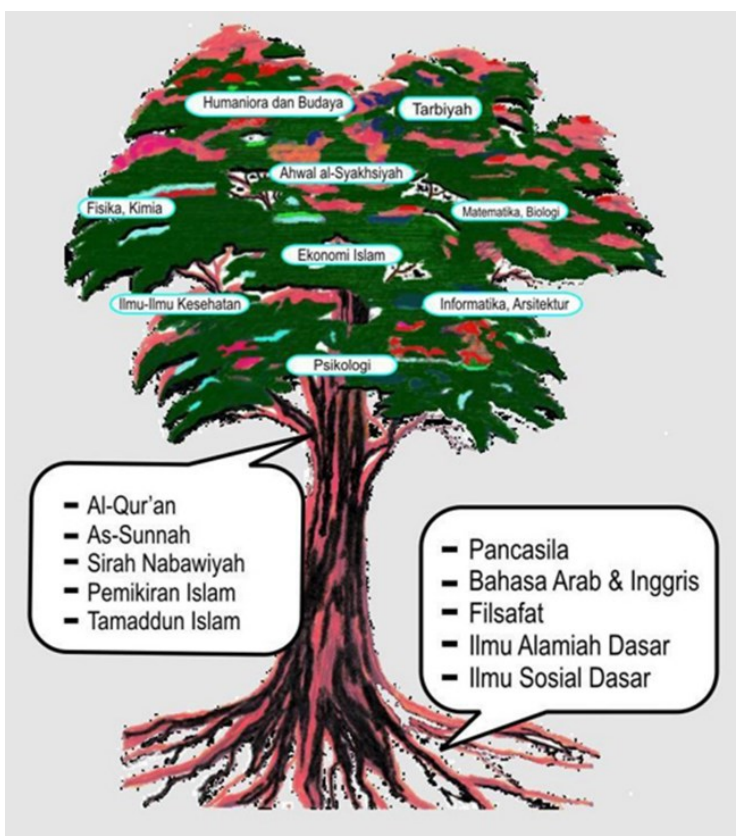

Picture 4

The Integration between Religious and General Sciences

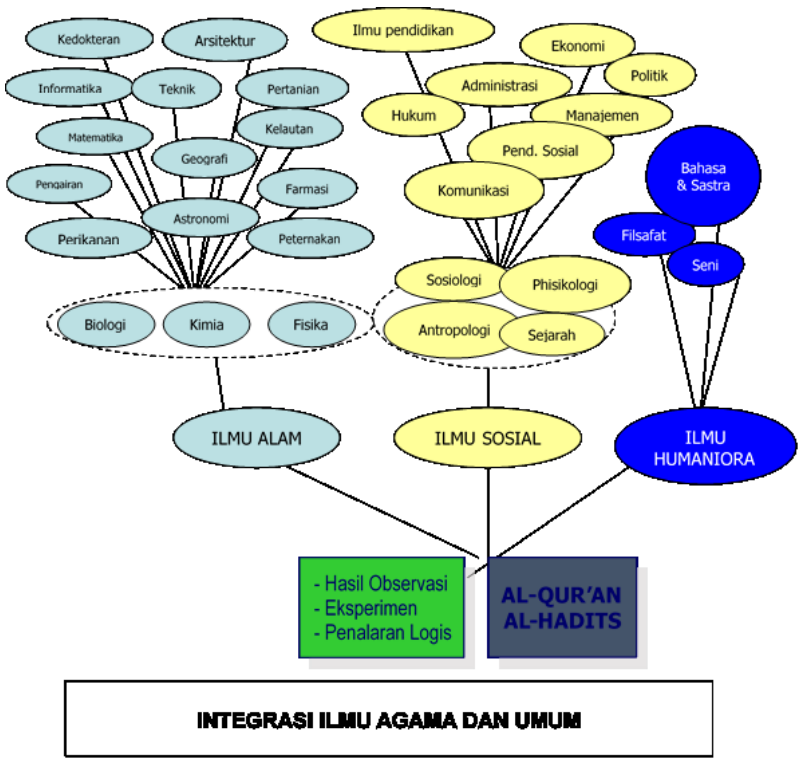

\section{REFERENCES:}

Arsyad, Azhar (2011). "the Real Khalifah" dalam Barizi dan Mujtahid (ed.), MembangunPendidikan Islam dalam Bingkai Islam Lintas Batas. Malang: UIN-Maliki Press.

Hady, Samsul dan Rasmianto. 2004. Konversi STAIN Malang Menjadi UIN Malang. Yogyakarta-Malang: Aditya Media-UIN Malang.

Muhaimin. (2005). Pengembangan

Kurikulum Pendidikan Agama Islam: di Sekolah Madrasah danPerguruan Tinggi. Raja Grafindo Persada. Jakarta

Muhaimin, Suti'ah, Prabowo (2009). ManajemenPendidikan: Aplikasinya dalam Penyusunan

Rice, G \&Bishoprick (1971). Conceptual Models of Organization. Merdith Corp. NY USA 
Suprayogo, Imam dan Rasmianto, (2008).

Perubahan Pendidikan Tinggi:

Refleksi Perubahan IAIN/STAIN

menjadi UIN. Malang: UIN-Malang

Press.

Suprayogo, Imam. (2009). Universitas

Islam Unggul: Refleksi Pemikiran

Pengembangan Kelembagaan dan

Reformulasi Paradigma Keilmuan

Islam. Malang: UIN-Malang Press.

\section{OTHER SOURCE:}

\section{Thesis, and Papers}

1. Musnandar, Aries. Soft Skills in Educational Management and Worldview of Islam. Paper presented at IIUM. May 15, 2012

2. Musnandar, Aries. The Thought of Islamic Scholars on Educational Management in Indonesia. Unpublished Article. PPs. UIN Maliki Malang, 2011.

3. In'ham Esha, Muhammad. Universitation of STAIN Malang: Policy Analysis of Institutional Change in the Perspective of Philisophy of Value. Paper for International Seminar, December 2-3, 2013.

SekolahPascasarjana UIN Maliki Malang

\section{INTERNET SOURCES}

1. Imam Suprayogo on Islamic Education. Retrieved April 20, 2013 from http://www.uinmalang.ac.id/index.php?option=com_c ontent\&view $=$ article $\& i d=3775$ : seman gat-universitas-al-azhar-mencariformat-kajian-islam\&catid $=25$ :artikelrektor

2. The Rector article files, 2012. Islam sebagai ajaran besar. Retrieved April 11, 2013 from http://www.uin- malang.ac.id/index.php?option $=$ com c ontent\&view $=$ article $\&$ id $=2811 \% 3$ Afile -rektor\&Itemid=367

3. Sekilas perjalanan metamorphosis STAIN, retrieved on Oct. 30, 2010 from http://ukpmkronika.blogspot.com/2010/10/sekilasperjalanan-metamorfosis-stain.html.

\section{NEWSPAPERS, MAGAZINES AND OTHERS}

1. Suprayogo, Imam. Paradigm of Scientific Development, State Islamic University Maulana Malik Ibrahim Malang, The Center of Excellence and Islamic Civilization, the Rector's presentation materials, unpublished article. 2012

2. Musnandar, Aries. Interview with Imam Suprayogo. March 2013.

\section{ISLAMIC REFERENCES}

1. The Holybook, Al Qur'an

2. Al Hadith 